\title{
Statistical Monitoring of Decrease of Surface Eccentricity and Hole of Barrel Tubes from High Strength Steels under the Production Conditions
}

Jozef Majerík ${ }^{1}$, Jozef Šandora ${ }^{1}$, Jaroslav Jambor ${ }^{2}$

${ }^{1}$ Faculty of Special Technology, Alexander Dubcek University of Trencin. Pri Parku 19, 91105 Trencin. Slovakia. Email: jozef.majerik@tnuni.sk

${ }^{2}$ Alexander Dubcek University of Trencin. Studentska 2, 911 50, Trencin. E-mail: jaroslav.jambor@tnuni.sk. Slovakia

This work investigates issues of BTA drilling of deep holes with slenderness ratio $L: D=45 \div 60$ of high strength steels with a tensile strength of $R m=1350 \div 1600$ MPa. Methodology for testing of surface when turning and boring deep holes after drilling accordingly, heat treatment, straightening annealing and stress relief, was based on the statistical monitoring of eccentricity surface deviation from the theoretical axis of the bore axis for instruments with changeable carbide cutting inserts with CVD/PVD coatings under operating conditions with the number of 30 pieces. Measurement results of eccentricity of surfaces for locating strips before and after machining (as in turning and drilling for more cuts) are statistically processed in tables and graphs, as well as the obtained and acquired results. Article presents the optimized parameters of BTA drilling. Originally used tools for drilling were upgraded by using carbide inserts of type 14.171.55-00/0400 or /0250 by Krupp WIDIA. Influences of factors are discussed, and the monitoring of factors that produce holes of desired eccentricity is presented.

Keywords: Barrel Tube, BTA System, Deep Hole Drilling, Surface Eccentricity, Statistical Monitoring

\section{Acknowledgement}

Author would like to acknowledge the experimental facility provided by the Faculty of Special Technology (A. D. University of Trencin) in cooperation with the ZTS production engineering company in Dubnica nad Vahom to carry out this experimental work and research.

\section{References}

[1] DUBOVSKA R., ŠANDORA, J., MAJERIK, J. (2014). Vítanie a výroba hlbokých otvorov, 261 p., Tisk J+K, Hradec Králové.

[2] ZABEL, A., HEILMANN, M. (2012). Deep hole drilling using tools with small diameters - Process analysis and process design. In: CIRP Annals - Manufacturing Technology, Vol. 61, pp. 111-114. Elsevier USA

[3] BIERMANN, D., SACHAROW, A., WOHLGEMUTH, K. (2009). Simulation of the BTA deep-hole drilling process. In: Production Engineering., Vol. 3, pp. 339-346. Springer Verlag.

[4] WEINERT, K., WEBBER, O, PETERS, C. (2005). On the influence of drilling depth dependent modal damping on chatter vibration in BTA deep hole drilling. In: CIRP Annals - Manufacturing Technology, Vol. 54, pp. 363366. Elsevier USA.

[5] RAMAKRISHNA RAO, P. K., SHUNMUGAM, M. S. (1987). Analysis of axial and transverse profiles of holes obtained in B.T.A. machining. In: International Journal of Machine Tools and Manufacture, Vol. 27, pp. 505515. Elsevier Limited.

[6] RAMAKRISHNA RAO, P. K., SHUNMUGAM, M. S. (1988). Wear studies in boring trepanning association drilling. In: Wear, Vol. 124, pp. 33-43. Elsevier BV.

[7] EL KHABEERY, M. M., SALEH, S. M., RAMADAN, M. R. (1991). Some observations of surface integrity of deep drilling holes. In: Wear, Vol. 142, pp. 331-349. Elsevier BV.

[8] SAKUMA K., TAGUCHI, K., KATSUKI, A. (1980). Study of deep hole drilling with solid boring tool. In: Bulletin of the JSME, Vol. 23, pp. 1921-1928.

[9] CHIN, J. H., WU, J. S. (1993). Mathematical models and experiments for chip signals of single-edge deep hole drilling. In: International Journal of Machine Tools and Manufacture, Vol. 33, pp. 507-519. Elsevier Limited.

[10] DENG, C. S., HUANG, J. C., CHIN, J. H. (2001). Effects of support misalignments in deep-hole drill shafts on hole straightness. In: International Journal of Machine Tools and Manufacture, Vol. 41, pp. 1165-1188. Elsevier Limited. 
[11] KATSUKI, A., SAKUMA, K., TAGUCHI, K., ONIKURA, H., AKIYOSHI, H., NAKAMUTA, Y. (1987). Influence of tool geometry on axial hole deviation in deep drilling: comparison of single and multi-edge tools. In: JSME International Journal, Vol. 30, pp. 1167-1174.

[12] CHIN, J. H., LEE, L. W. (1995). A study on the tool eigenproperties of a BTA deep hole drill-theory and experiments. In: International Journal of Machine Tools and Manufacture, Vol. 35, pp. 29-49. Elsevier Limited.

[13] CHIN, J. H., HSIEH, C. T., LEE, L. W. (1996). The shaft behavior of BTA deep hole drilling tool. In: International Journal of Mechanical Sciences, Vol. 38, pp. 461-482. Elsevier Limited.

[14] PERNG, Y. L., CHIN, J. H. (1999). Theoretical and experimental investigations on the spinning BTA deep-hole drill shafts containing fluids and subject to axial forces. In: International Journal of Mechanical Sciences, Vol. 41, pp. 1301-1322. Elsevier Limited.

[15] GAO, C. H., CHENG, K., KIRKWOOD, D. (2000). Investigation on the machining process of BTA deep hole drilling. In: Journal of Materials Processing technology, Vol. 107, pp. 222-227. Elsevier BV.

[16] CHIN, J. H., SHEU, S. D. (2007). Strengths and weaknesses of finite element modeling deep hole drilling as compared with beam and column equations. In: International Journal of Advanced Manufacturing Technology, Vol. 32, pp. 229-237. Springer London.

[17] DENG, C. S., CHIN, J. H. (2005). Hole roundness in deep-hole drilling as analysed by Taguchi methods. In: International Journal of Advanced Manufacturing Technology, Vol. 25, pp. 420-426. Springer London.

[18] RAMAKRISHNA RAO, P. K., SHUNMUGAM, M. S. (1987). Investigations into surface topography, microhardness and residual stress in Boring Trepanning Association machining. In: Wear, Vol. 119, pp. 89-100. Elsevier BV.

[19] MEHRABADI, I. M., NOURI, M., MADOLIAT, R. (2009). Investigating chatter vibration in deep drilling, including process damping and the gyroscopic effect. In: International Journal of Machine Tools and Manufacture, Vol. 49, pp. 939-946. Elsevier Limited.

[20] MESSAHOUD, A., WEIHS, C. (2009). Monitoring a deep hole drilling process by nonlinear time series modeling. In: Journal of Sound and Vibration, Vol. 321, pp. 620-630. Academic Press Inc.

[21] VASILKO, K., SIMKULET, V. (2012). Phenomenon of twist drill. In: Manufacturing Technology, Vol. 12, pp. 281-285.

[22] VASILKO, K. (2014). New experimental dependence of machining. In: Manufacturing Technology, Vol. 14, pp. 111-116.

[23] LATTNER, M., HOLESOVSKY, F. (2014). Effect of machining the load capacity notched components. In: $M a-$ nufacturing Technology, Vol. 14, pp. 47-50. 